\title{
Lembaga Jaminan Fidusia: Pasca Putusan Mahkamah Konstitusi Nomor 18/PUU-XVII/2019
}

\author{
Ari Wirya Dinata ${ }^{*}$ \\ ${ }^{1}$ Fakultas Hukum, Universitas Bengkulu, Indonesia \\ *Corresponding author's e-mail : aridinata@unib.ac.id
}

\begin{tabular}{|c|c|}
\hline ARTICLE INFO & AbStRACT \\
\hline $\begin{array}{l}\text { Keywords: } \\
\text { Fiduciary; MK Decision; Injury } \\
\text { Promise. } \\
\text { How To Cite: } \\
\text { Dinata, A.W. (2020). Lembaga Jaminan } \\
\text { Fidusia: Pasca Putusan Mahkamah } \\
\text { Konstitusi Nomor 18/PUU-XVII/2019. } \\
\text { Nagari Law Review, 3(2), 84-99. } \\
\text { DOI: } \\
\text { 10.25077/nalrev.v.3.i.2.p.84-99.2020 }\end{array}$ & $\begin{array}{l}\text { Fiduciary is one of the guarantees where the debtor has the right to control and take } \\
\text { advantage of the goods that are used as fiduciary security objects. Article } 15 \\
\text { paragraphs (1), (2), and (3) of Law Number } 42 \text { Year } 1999 \text { concerning Fiduciary } \\
\text { Guarantee regulates the execution mechanism for fiduciary security objects when } \\
\text { the fiduciary giver (debtor) experiences breach of promise to the fiduciary recipient } \\
\text { (creditor). So far, the execution mechanism for fiduciary security objects regulated } \\
\text { in the Act creates legal uncertainty and harms the debtor's rights. Because it gives } \\
\text { too much power to the creditor. The imbalance of power relations between debtors } \\
\text { and creditors towards the handling of the problem of breach of contract actually } \\
\text { causes an injustice in existing fiduciary institutions. The Constitutional Court, } \\
\text { through decision number } 18 \text { / PUU-XVII / 2019, tries to return the fiduciary } \\
\text { institution to the spirit of equilibrium relations between debtors, creditors, and fair } \\
\text { fiduciary guarantees. After the decision of the Constitutional Court Number } 18 \text { / } \\
\text { PUU-XVII / 2019. Has there been a harmonious power relationship between two } \\
\text { legal subjects in fiduciary guarantees. This paper examines the pre and post } \\
\text { fiduciary guarantee institutions of the Constitutional Court and analyzes the legal } \\
\text { consequences that occur. This paper uses a type of juridical-normative research } \\
\text { using primary data and primary, secondary and tertiary legal material. While the } \\
\text { analysis method uses qualitative methods. }\end{array}$ \\
\hline
\end{tabular}

(O2020 NALREV. Faculty of Law Universitas Andalas

\section{Pendahuluan}

Perkembangan fidusia mulai pesat dalam pelbagai kegiatan ekonomi dan bisnis karena lembaga jaminan dengan fidusia dapat memenuhi kebutuhan dalam menjalankan kegiatan ekonomi dan bisnis. Hal ini terjadi karena masalah lembaga jaminan fidusia memiliki hubungan erat dengan perjanjian kredit bank atau lembaga pembiayaan lainnya. Dimana debitur akan meminjam kredit pada bank guna keperluan perluasaan usahanya atau memenuhi kebutuhan pribadi lainnya tidak dapat memberikan jaminan lain selain barang bergerak seperti mesin-mesin kendaraan, dan lain-lain yang sedang dipakai dalam kegiatan usahannya.

Dalam khasanah Hukum perdata terdapat sejumlah instrumen yang digunakan sebagai jaminan/ agunan. Dimana setiap instrumen tersebut memiliki karakteristiknya masing-masing. Semua itu dapat digolongkan dalam objek yang berbeda-beda. Seperti jaminan benda bergerak, benda tidak bergerak, benda berwujud, benda tidak berwujud, benda yang haknya berada pada si pemberi hak atau 
diserahkan kepada si penerima hak vis versa. Diantara jaminan tersebut adalah gadai, hak tanggungan, creditverband, hipotek, dan fidusia.

Awalnya masalah fidusia ini dianggap sebagai gadai gelap. Karena konsep gadai dan fidusia memiliki kemiripan namun tak serupa karena pada gadai penguasaan atas barang yang dijadikan objek gadai berada pada kreditur sedang dalam fidusia pemberi fidusia tetap menguasai dan menerima manfaat dari beda yang dijadikan objek jaminan fidusia.

Lembaga fidusia bagi bangsa Indonesia bukan merupakan suatu lembaga yang baru. Sudah sejak lama bangsa Indonesia mengenal lembaga jaminan tersebut. Bahkan dalam penjelasan UU Fidusia dikatakan bahwa lembaga fidusia sudah diakui sejak jaman penjajahan Belanda. Bedanya, bahwa lembaga fidusia yang selama ini dikenal didasarkan atas yurisprudensi. Yuriprudensi tersebut adalah terkait kasus pada tahun 1932 dalam arrest HGH perkara BPM Clignet pada zaman Hindia Belanda. Kemudian terakhir dalam putusan Mahkamah Agung Nomor 372 K/Sip/1970 tanggal 1 september 1971 dan Putusan Mahkamah Agun Republik Indonesia Nomor 227K/Sip/1977,tanggal 2 Februai 1980. ${ }^{1}$

Selain itu, lembaga fidusia yang selama ini digunakan bersifat sederhana, mudah, dan cepat tetapi di lain pihak lembaga itu dianggap tidak menjamin adanya kepastian hukum. Karena pengaturan lembaga fidusia yang memberikan celah hukum (loophole) untuk ditafsir berbeda antara satu pihak dengan pihak lain. ketentuan yang demikian pada akhirnya menimbulkan ketidakpastiaan hukum yang pada akhirnya dapat merugikan para pihak. padahal seperti yang dinukilkan oleh Gustav Radbruch tujuan hukum terdiri atas 3(tiga) unsur yaitu kepastian hukum, keadilan dan kemanfaatan. Bagaimana mungkin suatu aturan hukum dapat memberikan kemanfaatan dan keadilan tatkala aturan hukum tersebut tidak memberikan kepastian hukum dalam penegakannya.

Jaminan $^{2}$ adalah sesuatu benda atau barang yang dijadikan sebagai tanggungan dalam bentuk pinjaman uang. Menurut Kamus Bahasa Indonesia Jaminan diartikan sesuatu yang diberikan kepada kreditur untuk menimbulkan keyakinan bahwa debitur akan memenuhi kewajiban yang dapat dinilai dengan uang yang timbul dari suatu perikatan. ${ }^{3}$ Sejalan dengan yang diutarakan sepakati dalam seminar Badan Pembinaan Hukum Nasional di Yogyakarta Tahun 1977 yang mendefinisikan Jaminan adalah menjamin dipenuhinya kewajiban yang dapat dinilai dengan uang yang timbul dari suatu perikatan hukum ${ }^{4}$.

Hukum jaminan tergolong bidang hukum yang populer khususnya dalam hukum ekonomi dan bisnis.(the economic law, wiertschafrecht, atau droit econonique). Hukum jaminan mempunyai fungsi menunjang kemajuan ekonomi dan kemajuan pembangunan umumnya. ${ }^{5}$ karena jaminan memberikan kesempatan untuk pengembangan dan pertumbuhan ekonomi tatkala para pihak memiliki keterbatasan atas akses sumber daya (capital) dalam mengembangkan kegiatan ekonominya. Dengan adanya sesuatu yang dapat dijadikan jaminan memberikan kesempatan kepada debitur untuk

1 Sugianto, 2014. "Rekontruksi Perjanjian Fidusia atas Benda Bergerak yang didaftarkan Berdasarkan Nilai Keadilan”, Jurnal Pembaharua Hukum, Vol.1 No. 3 September-Desember 2014, hlm. 339

2 Istilah Jaminan merupakan terjemahan dari bahasa Belanda yaitu "Zakerheid" atau "cautei" yang mencakup secara umum cara kreditor menjamin dipenuhinya tagihannya, disamping pertanggungjawaba umum debitor terhadap barang-barangnya.

3 H.U Adil, 2016, Dasar-Dasar Hukum Bisnis Edisi 2, (Jakarta: Mitra Wacana Media) hlm 108

$4 \quad$ Ibid, hlm. 109

5 Titik Triwulan Tutik, 2014, Hukum Perdata dalam Sistem Hukum Nasional, (Jakarta: Kencana) hlm 175 
mendapatkan hak manfaat lainnya guna mengembangkan kegiatan ekonomi atau memenuhi kebutuhan ekonomi lainnya.

Hukum Jaminan diartikan sebagai keseluruhan norma hukum yang mengatur hubungan hukum antara pemberi dan penerima jaminan dalam kaitannya dengan pembebanan jaminan untuk mendapatkan fasilitas kredit. Adapun yang menjadi unsur-unsur dalam hukum jaminan adalah sebagai berikut: ${ }^{6}$

1. Adanya kaedah hukum baik yang tertulis maupun yang tidak tertulis;

2. Adanya pemberi dan penerima jaminan;

3. Adanya jaminan;

4. Adanya fasilitas kredit.

Pada umumnya jenis-jenis lembaga jaminan yang dikenal dalam tata hukum Indonesia dikelompokan menjadi: ${ }^{7}$

1. Menurut cara terjadinya, yaitu jaminan yang lahir karena undang-undang dan perjanjian;

2. Menurut sifatnya, yaitu jaminan yang bersifat kebendaan dan bersifat perseorangan;

3. Menurut kewenangan menguasainya, yaitu jaminan yang menguasai bendanya dan tanpa menguasai bendanya.

4. Menurut golongannya, yaitu jaminan yang tergolong jaminan umum dan jaminan khusus. Jaminan fidusia didefinisikan sebagai hak jaminan atas benda bergerak baik yang berwujud maupun tidak berwujud dan benda tidak bergerak, termasuk bangunan yang tidak dapat dibebani hak tanggungan sebagaimana dimaksud dalam UU No 4 Tahun 1992 tentang Hak Tanggungan. Jaminan fidusia memberikan kedudukan yang diutamakan kepada penerima fidusia terhadap kreditor lainnya. Berdasarkan definisi tersebut maka objek dari jaminan fidusia dapat dikategorikan menjadi 2 (dua) macam yaitu: (a) Benda bergerak baik yang berwujud maupun yang tidak berwujud dan (b) Benda tidak bergerak, khususnya bangunan yang tidak dibebani hak tanggungan, berkaitan dengan pembebanan jaminan rumah susun. Sedangkan aktor dalam jaminan fidusia dapat pula dipetakan kedalam 2 (dua) kelompok yaitu:8 (a).Pemberi fidusia, yaitu orang perorangan atau korporasi pemilik benda yang menjadi objek jaminan fidusia dan (b). Penerima fidusia, yaitu orang perorangan atau korporasi yang mempunyai piutang yang pembayarannya dijamin dengan jaminan fidusia.

Problematika hukum yang kerapkali terjadi dalam hukum jaminan baik jaminan fidusia maupun jaminan lainnya adalah masalah eksekusi terhadap objek jaminan ketika terjadi cidera janji (wan prestasi) dari debitur. Dalam pelbagai kasus cidera janji terhadap objek jaminan fidusia dilakukan secara semena-mena oleh kreditur tanpa memperhatikan hak debitur sebagai patner pihak. sehingga seringkali permasalahan ini menimbulkan masalah hukum yang pelik.

Fidusia telah lama dikenal sebaga salah satu instrumen jaminan kebendaan bergerak yang bersifat nonpossesory. Berbeda dengan jaminan kebendaan bergerak yang bersifat possesory, karena jaminan fidusia memungkinkan debitur sebagai pemberi jaminan tetap memanfaatkan nilai ekonomi dari suatu

\footnotetext{
Op cit. hlm. 109

Titik Triwulan Tutik, op cit. 176

H. Salim HS, 2012, Perkembangan Hukum Jaminan di Indonesia, (Jakarta: Rajawali Press) hlm. 64
} 
kebendaan yang dijadikan objek fidusia. ${ }^{9}$ Kehadiran jaminan fidusia hakikinya juga melengkapi kebutuhan atas hak jaminan lain yang belum dapat mengakomodir kebutuhan atas model baru dari perihal jaminan. Meski dalam prakteknya jaminan fidusia tidak sesederhana makna harfiahnya. Karena terdapat banyak pula langgam yang dipraktekannya.

Didalam praktek sehari-hari, banyak pihak dalam perjanjian hutang-piutang dengan jaminan benda bergerak mencampur adukan pengertian leasing, "hire purchase" dan beli dengan angsuran. Contohnya didalam hire purchase benda yang menjadi objek perjanjian sebenarnya masih tetap milik kreditur sampai bendanya lunas dibayar. Namun dalam praktek tidak jarang BPKB suatu kendaraan sudah atas nama debitur, antara lain untuk menghindari bea balik nama dan pajak, namun diperjanjikan bahwa, debitur hanya sebagai peminjam pakai saja. Sebenarnya jika BPKB sudah atas nama debitur, maka harus ditandatangani suatu perjanjian fidusia. ${ }^{10}$

Contoh kasus yang berkaitan dengan jaminan fidusia adalah perkara Republik Indonesia v Amin Zuhri dan Heri Siswanto 1241K/Pid/1986 tahun 1989. Kreditur dikenakan sanksi pidana karena mengambil langsung barang jaminan yang tanda bukti pemilikannya sudah atas nama debitur. ${ }^{11}$ Kasus-kasus tersebut terus terjadi dari waktu ke waktu sebab pengaturan mengenai Undang-Undang Nomor 42 Tahun 1999 tentang Jaminan Fidusia sebagai politik hukum perundang-undangan memiliki kelemahan dalam mengakomodir kebutuhan hukum perihal terjadi cidera janji dan pelaksanaan eksekusi atas objek jaminan fidusia. Oleh karenannya putusan Nomor 18/PUU-XVII/2019 pengujian Pasal 15 ayat (2) dan ayat (3) Undang-Undang Nomor 42 Tahun 1999 tentang Jaminan Fidusia telah memodifikasi dan membentuk paradigma baru dalam isu jaminan fidusia dalam sistem hukum Indonesia. tulisan ini bermaksud menyigi mengenai lembaga jaminan fidusia pre dan post putusan Mahkamah Konstitusi berserta dengan semua problematikanya.

\section{Metode Penelitian}

Tulisan ini dibuat dengan menggunakan metode penelitian hukum yuridis normatif yang merujuk kepada aturan atau norma yuridis yang berkaitan dengan jaminan fidusia. Adapun jenis data yang digunakan adalah data sekunder berupa bahan hukum primer, bahan hukum sekunder dan bahan hukum tersier. Dalam penyajian ulasan dan elaborasi isu, tulisan ini menggunakan analisa kualitatif

9 Nur Hayati, Aspek Hukum Pendaftaran Jaminan Fidusia Berdasarkan Undang-Undang Nomor 42 Tahun 1999 tentang Jaminan Fidusia, Jurnal Lex Jurnalica Volume 13 Nomor 2 Agustus 2016, hlm. 147

10 Erman Rajaguguk, 1998, Transaksi Berjaminan dalam Berbagai Putusan Pengadilan di Indonesia dalam Seri Hukum Ekonomi: Hukum Jaminan Indonesia, (Jakarta: Elips) hlm. 31

11 Dalam perkara ini, Arifin membeli sepeda motor merek suzuki dari PT Karwisan Motor, Surabaya, secara angsuran sewa beli dengan menanda tangani perjanjian sewa beli (kuurkop) tanggal 24 November 1982. Sepeda motor diserahkan kepada Arifin beserta STNK yang tertulis nama Arifin. Arifin berkewajiban membayar angsuran kreditnya tiap bulan namun ditengah perjalanan kredit macet. Dengan berpegang kepada surat kuasa yang diberikan oleh Arifin kepada PT Karwisan Motor, pada saat penandatanganan perjanjian sewa beli. Petugas PT mendatangi rumah Arifin dan mengambil paksa motor. Tindakan tersebut dilaporkan oleh Arifin ke polisi. Jaksa menuntut kedua terdakwa berdasarkan Pasal 335 (1) KUHP. Di Pengadilan Negeri memenangkan PT Karwisan dengan dalil pembeli hanya sebagai penyewa. Oleh karenannya Arifin bukan pemilik motor tersebut. Oleh karenannya tuntutan Jaksa mengenai Pasal 335 (1) tidak terbukti. Namun pada sidang kasasi, MA berpendapat pengambilan sepeda motor harus mendapat izin dari Arifin, karena STNK sudah mencantumkan namannya, walaupun ada perjanjian bahwa PT Karwisan dapat mengambil motor tersebut dari tangan Arifin. MA menghukum terdakwa 1 bula dalam masa percobaan 3 bulan. 
dengan mengungkapkan argumentasi-argumentasi hukum berkaitan dengan lembaga jaminan fidusia di Indonesia.

\section{Pembahasan}

\subsection{Selayang Pandang Jaminan Fidusia}

Kata fidusia secara harfiah pada awalnya berasal dari kata "fides" yang mempunyai arti kepercayaan. Sesuai dengan arti atau makna dari kata tersebut, maka hubungan hukum antara debitur (pemberi fidusia) dan kreditur (penerima fidusia) merupakan hubugan yang didasarkan atas kepercayaan. ${ }^{12}$ Pemberi fidusia percaya bahwa penerima mau mengembalikan hak milik barang yang telah diserahkan setelah dilunasi utangnya, vis versa penerima fidusia percaya bahwa pemberi fidusia tidak akan menyalahgunakan barang jaminan yang berada dalam kekuasaannya.

Di Belanda kata Fidusia. Secara terminologi berasal dari istilah lengkap dalam bahasa Belanda disebut fiducia eigendom overdracht ${ }^{13}$ atau dalam Bahasa Inggris disebut fiduciary transfer of ownership. ${ }^{14}$ Fidusia adalah suatu pemindahan milik secara kepercayaan. Perkataan fidusia yang berarti "secara kepercayaan" ditujukan kepada suatu kepercayaan yang timbal balik sifatnya. Kepercayaan tersebut diberikan oleh satu pihak kepada pihak lain bahwa apabila tampak keluar berwujud pemindahan hak milik, akan tetapi ke dalam (intern) sebenarnya hanyalah berupa suatu jaminan saja untuk suatu utang. ${ }^{15}$

Pranata jaminan fidusia sudah dikenal dan diberlakukan dalam masyarakat hukum Romawi. Ada dua bentuk jaminan fidusia yaitu fidusia cum creditore dan fidusia cum amico. Keduanya timbul dari perjanjian yang disebut factum fiduciae yang kemudian diikuti dengan penyerahan hak atau in iure cessio. 16

Dalam hukum Islam jaminan dikenal dengan istilah Ar-Rahn (barang jaminan). Ar rahn ditangan al mutahin (pemberi utang) hanya berfungsi sebagai jaminan utang ar rahin (orang yang berhutang). Barang jaminan itu baru boleh dijual/dihargai apabila dalam waktu yang disetujui kedua belah pihak. ${ }^{17}$

Berdasarkan Pasal 1 angka 1 Undang-undang Nomor 42 Tahun 1999 tentang Fidusia. dinyatakan bahwa Fidusia adalah pengalihan hak kepemilikan suatu benda atas dasar kepercayaaan dengan ketentuan

12 Sobirin, 2008, Kajian Hukum Terhadap Pendaftaran Jaminan Fidusia di Kantor Pendaftaran Fidusia Daerah Khusus Ibukota Jakarta, Tesis: Program Studi Magiste Kenotariatan Pasca Sarjana Universitas Diponegoro hlm. 15

13 Kadang-kadang dalam litelatur Belanda istilah yang digunakan untuk menyebut Fidusia adalah sebagai berikut:

a) Zekerheid-eingendom (hak milik sebagai jaminan);

b) Bezitloos zekerheidsrecht (jaminan tanpa menguasai);

c) Verruind pand begrip (gadai yang diperluas);

d) Eigendomsoverdracht tot zekerheid (penyerahan hak milik secara jaminan);

e) Bezitloos pand (gadai berselebung);

f) Een verkapt pand recht ( gadai berselebung);

g) Uitbaouw dari pand (gadai yang diperluas).

14 Munir Fuady, 2013, Hukum Jaminan Utang, (Jakarta: PT Erlangga) hlm.. 101

15 Erman Rajaguguk, op cit. hlm. 45

16 Jatmiko Winarno, 2015. "Perlindungan Hukum Bagi Kreditur pada Perjanjian Jaminan Fidusia", Jurnal Independent. No 3, Vol.7, hlm. 45

17 M Yasir, 2016. “Aspek Hukum Jaminan Fidusia”, Salam Jurnal Sosial \& Budaya Syari,I, Vol. 3 No. 1 hlm. 76 
bahwa benda yang hak kepemilikan suatu benda atas dasar kepercayaan dengan ketentuan bahwa benda yang hak kepemilikannya diadakan tersebut tetap dalam penguasaan pemilik benda itu.

Masalah fidusia di Indonesia telah berkembang sejak tahun 1931. Hal ini dibuktikan dengan adanya yurisprundesi (arrest HGH dalam perkara BPM-Cligent) ${ }^{18}$ pada tahun tersebut. Hal itu berarti bahwa masalah fidusia di Indonesia oleh yurisprudensi tersebut telah diakui keberadaannya. ${ }^{19}$

Jaminan pemberian utang oleh kreditur terhadap debitur telah diatur dengan undang-undang. Dalam hukum jaminan terdapat 2 (dua) asas umum mengenai jaminan, yaitu:20

1. Dalam Pasal 1131 KUH Perdata, yang menentukan bahwa segala harta kekayaan debitur, baik berupa benda bergerak maupun benda tetap, baik yang sudah ada maupun yang akan ada dikemudian hari, menjadi jaminan atau agunan bagi semua perikatan yang dibuat oleh debitur dengan para kreditur;

2. Dalam Pasal 1132 KUH Perdata, menyebutkan bahwa apabila debitur wanprestasi, maka hasil penjualan atas semua harta kekayaan atas debitur tanpa terkecuali, merupakan sumber bagi pelunasan utangnya.

Sedangkan asas mengenai hak jaminan dalam hukum jaminan terdiri atas:21

1. Asas teritorial;22

2. Asas aksesoir; 23

3. Asas hak preferensi; ${ }^{24}$

4. Asas non- distribusi; ${ }^{25}$

5. Asas publisitas; 26

6. Asas eksistensi benda;27

7. Asas eksistensi perjanjian pokok;28

8. Asas larangan janji benda jaminan dimiliki untuk sendiri;29

18 Pertama kali lembaga fidusia diakui secara hukum dengan diatur didalam Undang-Undang Nomor 16 Tahun 1985 tentang Rumah Susun. Dimana rumah susun yang pada hakikatnya adalah benda tidak bergerak yang bukan termasuk objek fidusia yang berupa benda bergerak. Namun rumah susun dijadikan benda tidak bergerak yang dikecualikan dapat dijadikan objek jaminan fidusia bukan objek hak tanggungan atau hipotik.

19 Erman Rajaguguk, op cit. hlm. 45

20 H.U Adil, op cit. hlm. 114

21 Ibid, hlm.115

22 Menentukan barang jaminan yang ada di suatu negara hanya dapat dijadikan jaminan hutang apabila perjanjian hutang maupun pengingkatan hipotik tersebt dibuat dinegara tersebut.

23 Asas yang merujuk pada Pasal 1821 KUH Perdata yang menyebutkan bahwa suatu perjanjian dapat diadakan apabila terdapat perjanjian pokoknya.

24 Pihak kreditur kepada siapa debitur telah menjamin hutangnya pada umumnya mempunyai hak atas jaminan kredit tersebut untuk perlunasan hutangnya yang mesti didahulukan dari kreditur lainnya.

25 Suatu hak jaminan tidak dapat dipecah-pecah kepada beberapa kreditur

26 Suatu jaminan hutang harus dipublikasikan sehingga diketahui oleh khalayak umum.

27 Suatu hipotik atau hak tanggungan hanya dapat diletakan pada benda yang benar-benar ada.

28 Benda jaminan dapat diikat setelah adanya perjanjian pokok.

29 Asas yang melarang kreditur untuk memiliki benda jaminan untuk diri sendiri. 
9. Asas formalism; ${ }^{30}$

10. Asas mengikuti benda. ${ }^{31}$

\subsection{Pembebanan, Pendaftaran Hak Jaminan Fidusia, dan Hapusnya Fidusia}

Pembebanan jaminan fidusia diatur dalam Pasal 4 sampai Pasal 10 UU No 42 Tahun 1999. Sifat jaminan fidusia adalah perjanjian ikutan dari suatu perjanjian pokok yang menimbulkan perjanjian bagi para pihak untuk memenuhi suatu prestasi. Pembebanan jamina fidusia dilakukan dengan cara sebagai berikut: 32

1. Dibuat dengan akta notaris dalam bahasa Indonesia. akta jaminan sekurang-kurangnya memuat:

a. Identitas para pihak pemberi fidusia;

b. Data perjanjian pokok yang dijamin fidusia;

c. Urairan mengenai benda yang menjadi objek jaminan fidusia;

d. Nilai penjaminan; dan

e. Nilai benda yang menjadi jaminan fidusia.

2. Utang yang perlunasannya dijaminkan dengan jaminan fidusia adalah:

a. Utang yang telah ada;

b. Utang yang akan timbul dikemudian hari yang telah diperjanjikan dalam jumlah tertentu;

c. Utang yang pada utang eksekusi dapat ditentukan jumlahnya berdasarkan perjanjian pokok yang menimbulkan kewajiban memenuhi suatu prestasi.

3. Jaminan fidusia dapat diberikan kepaa lebih dari satu penerima fidusia atau kuasa atau wakil dari penerima fidusia;

4. Jaminan fidusia dapat diberikan terhadap satu atau lebih satuan atau jenis benda termasuk piutang, baik yang telah pada saat jaminan diberikan maupun yang diperoleh kemudian. Pembebanan atas benda atau piutang yang diperoleh kemudian tidak dapat dilakukan dengan perjanjian jaminan tersendiri kecuali diperjanjikan lain, seperti:

a. Jaminan fidusia, meliputi hasil dari benda yang menjandi objek jaminan fidusia;

b. Jaminan fidusia meliputi klaim asuransi, dalam hal benda yang menjadi objek jaminan fidusia diasuransikan.

30 Terdapat tata cara atau prosesi yang telah diatur dalam undang-undang untuk membuat atau melaksanakan suatu perjanjian, antara lain adanya keharusan untuk pembuatan akta, keharusan untuk melakukan pencatatan, keharusan untuk melaksanakan didepan pejabat tertentu, keharusan penggunaan instrumen tertentu, dan adanya keharusan penggunaan kata-kata tertentu dalam perjanjian.

31 Hak kebendaan sehingga hak jaminan akan selalu ada pada suatu benda yang telah dijaminkan walaupun benda tersebut telah berpindah kepemilikannya.

32 M. Bahsan, 2012, Hukum Jaminan dan Jaminan Kredit Perbankan Indonesia, (Jakarta: Rajawali Press) hlm. 53 
Pendaftaran hak tanggungan diatur dalam Pasal 11 sampai Pasal 18 UU No 42 Tahun 1999 tentang Jaminan Fidusia. Pendaftaran dilakukan di kantor pendaftaran fidusia. Secara sistematis, tata cara pendaftaran adalah sebagai berikut: ${ }^{33}$

1. Penerima fidusia, kuasa atau wakilnya mengajukan permohonan pendaftaran fidusia pada kantor pendaftaran fidusia;

2. Kantor pendaftaran fidusia mencatat jaminan fidusia dalam buku daftar fidusia pada tanggal yang sama dengan tanggal penerimaan permohonan pendaftaran;

3. Membayar biaya pendaftaran fidusia;

4. Kantor pendaftaran fidusia menerbitkan dan menyerahkan sertifikat jaminan fidusia kepada penerima fidusia pada tanggal yang sama dengan penerimaan permohonan pendaftaran;

5. Jaminan fidusia lahir pada tanggal yang sama dengan tanggal dicatatnya jaminan fidusia dalam buku daftar fidusia.

Apabila sertifikat jaminan atas perubahan diajukan kepada substansi, maka:

1. Permohonan pendaftaran atas perubahan diajukan kepada kantor pendaftaran fidusia;

2. Kantor pendaftaran fidusia pada tanggal yang sama dengan tanggal penerimaan permohonan perubahan, melakukan pencatatan perubahan tersebut dalam buku daftar fidusia dan menerbitkan pernyataan perubahaan yang merupakan bagian tak terpisahkan dari sertifikat jaminan fidusia.

Jaminan Fidusia akan hapus disebabkan oleh 3 (tiga) ketentuan berikut:

1. Hapusnya utang yang dijamin dengan fidusia yaitu karena pelunasan dan bukti hapusnya utang berupa keterangan yang dibuat oleh kreditur;

2. Pelepasan hak atas jaminan fidusia oleh penerima fidusia;

3. Musnahnya benda yang menjadi objek jaminan fidusia.

\subsection{Eksekusi dalam Jaminan Fidusia}

Eksekusi adalah penyitaan dan penjualan benda yang menjadi objek jaminan fidusia. Eksekusi timbul karena debitor cedera janji atau tidak memenuhi prestasinya tepat pada waktunya kepada kreditur. Eksekusi jaminan diatur dalam Pasal 29 sampai Pasal 34 UU No 42 Tahun 1999 tentang Jaminan Fidusia. Ada 4 (empat) cara eksekusi jaminan fidusia, antara lain adalah sebagai berikut:

33 M. Bahsan, ibid, hlm. 56 
1. Pelakasanaan title eksekutorial ${ }^{34}$ oleh penerima fidusia, yaitu kekuatan eksekusi yang sama dengan putusan pengadilan ${ }^{35}$ yang telah memperoleh kekuatan hukum tetap; ${ }^{36}$

2. Penjualan benda yang menjadi objek jaminan fidusia atau kekuasaan penerima fidusia sendiri melalui pelelangan umum; 37

3. Penjualan di bawah tangan yang dilakukan berdasarkan kesepakatan pemberi dan penerima fidusia. 38

Sedangkan menurut Munir Fuady ada 5 (lima) jenis eksekusi jaminan fidusia selain dari 3 (tiga) yaitu sebagai berikut: ${ }^{39}$

1. Eksekusi fidusia secara lelang sendiri tanpa melalui kantor lelang; ${ }^{40}$

2. Eksekusi fidusia secara mendaku;41

3. Eksekusi fidusia terhadap barang perdagangan dan efek yang dapat diperdagangkan;42

4. Eksekusi fidusia lewat gugatan biasa;

5. Eksekusi fidusia menurut UU No 16 Tahun 1985 tentang Rumah Susun.

34 Menurut Kitab Undang-Undang Hukum Acara Perdata (HIR), Setiap kata yang mempunyai titel eksekutorial dapat dilakukan fiat eksekusi. Jika tidak dengan jalan damai, maka surat yang demikian dieksekusi dengan perintah dan dibawah pimpinan ketua pengadilan negara (yang daerah hukumnya mencakup daerah hukum debitur)

35 Dalam Pasal 15 UU Fidusia disebutkan adanya kata "Demi Keadilan Berdasarkan Ketuhanan Yang MahaEsa" dalam sertifikat jaminan fidusia membuat sertifikat fidusia memiliki kekuatan eksekutorial yang sama dengan putusan pengadilan yang memperoleh kekuatan hukum penuh. Karena itu, yang dimaksud dengan fiat eksekusi adalah eksekusi atas sebuah akta hanya saja, tidak jelas dalam UU Fidusia disebutkan apabila pemberi hak fidusia keberatan atas eksekusi itu lalu mengajukan keberatan bagaimana prosedur keberatannya dan siapa yang memutus keberatan tersebut. Seakan-akan ada celah hukum (loop hole) dalam UU No 42 Tahun 1999, tatkala ada keberatan atas fiat eksekusi atas objek fidusia.

36 Ada beberapa akta yang mempunyai title eksekutorial, yang disebut dengan istilah grosse akta yaitu:

a) Akta hipotek (berdasarkan Pasal $224 \mathrm{HIR}$ );

b) Akta pengakuan utang ( berdasarkan Pasal $224 \mathrm{HIR}$ );

c) Akta Hak Tanggungan ( berdasarkan Pasal 14 UU No 4 Tahun 1996);

d) Akta Fidusia ( berdasarkan Pasal 15 UU No 42 Tahun 1999).

37 Diatur dalam Pasal 29 ayat (1) huruf b. Ketentuan ini menghapuskan keragu-raguan sebelumnya bahwa seolah-olah setiap eksekusi lewat kantor pelelangan umum harus dengan suatu penetapan pengadilan, pada hal, menurut Fuady anggap ini tidak benar sama sekali.

38 Jaminan fidusia dapat juga dieksekusi secara parate eksekusi (mengesksekusi tanpa lewat pengadilan) dengan cara menjual benda objek fidusia secaa dibawah tangan, asalkan terpenuhinya syarat-syarat sebagaimana diatur dalam UU Fidusia.

39 Munir Fuady, 2013, Hukum Jaminan Utang, (Jakarta: PT Erlangga) hlm. 145-147

40 Cara penjualan seperti ini dapat dianggap sebagai salah satu varian dari eksekusi secara parate (mengeksekusi tanpa pengadilan) dengan cara menjual sendiri objek jaminan fidusia tersebut langsung tanpa melalui perantara kantor lelang.

41 Yang dimaksud dengan eksekusi fidusia mendaku adalah eksekusi fidusia dengan cara mengambil barang fidusia untuk menjadi milik kreditur secara langsung tanpa lewat transaski apapun. Keabsahan eksekusi ini menurut Munir disebutkan institusi hukum fidusia ini dianggap sebagai suatu penyerahan hak milik secara kepercayaan. Maksudnya obje fidusia tersebut sudah berpindah kepemilikannya kepada kreditor sementara kreditur menyerahkan penguasaanya atas benda tersebut kepada debitr berlandaskan kepercayaan.

42 Jika benda yang menjadi objek fidusia merupakan benda perdagangkan atau efek yang dijual di bursa maka eksekusi baang dapat dilakukan dengan cara penjualan di pasar atau di bursa sesuai Pasal 31 UU fidusia 
Secara implisit Undang-Undang Jaminan Fidusia mengatur mengenai lembaga parate eksekusi. Dasar berpijaknya adalah Pasal 15 ayat (1), ayat (2) dan ayat (3). Yang memberikan keleluasaan bertindak atau executoriale titel yang menimbulkan suatu ketentuan eksekutorial suatu daya paksa. Dengan prosedur setelah ketua pengadilan negeri menerima permohonan dari kreditur selaku pemegang jaminan fidusia, maka ketua pengadilan negeri terlebih dahulu memanggil debitur untuk memberitahukan dan memperingatkan (aanmaning), maka proses pelelangan atas pemegang jaminan fidusia sebagai jaminan akan dilaksanakan penjualan secara lelang. ${ }^{43}$

Sedangkan Pasal 15 ayat (3) UU Jaminan Fidusia menyebutkan "apabila debitur cidera janji, penerima fidusia mempunyai hak untuk menjual benda yang menjadi objek jaminan fidusia atas kekuasaanya sendiri". Prosedur eksekusi sebagaimana dimaksudkan Pasal 15 ayat (3) UU Jaminan Fidusia, kreditur cukup mengajukan permohonan untuk pelaksanaan lelang kepada kantor lelang negara. Kewenangan itu tidak diperoleh dari pemberi objek jaminan fidusia tapi sudah dengan sendirinya ada padannya, atas dasar undang-undang sendiri yang memberikan kepadannya.

Ada 3 (tiga) kemungkinan dari hasil pelelangan atau penjualan barang jaminan fidusia adalah sebagai berikut:

1. Hasil eksekusi sama dengan nilai pinjaman, maka utangnya dianggap lunas;

2. Hasil eksekusi melebihi penjaminan, penerima fidusia wajib mengembalikan kelebihan tersebut kepada pemberi fidusia;

3. Hasil eksekusi tidak mencukupi untuk pelunanasan utang, pemberi fidusia tetap bertanggung jawab atas kekurangan pembayaran.

Dua (2) janji yang dilarang dalam pelaksanaan eksekusi objek jaminan fidusia yaitu:

1. Janji melaksanakan eksekusi dengan cara yang bertentangan dengan Pasal 29 UU No 42 Tahun1999;

2. Janji yang memberi kewenangan kepada penerima fidusia untuk memiliki objek jaminan fidusia apabila pemberi fidusia cedera janji.

\subsection{Mahkamah Konstitusi dan Mahkota Putusan MK}

Mahkamah Konstitusi adalah lembaga negara baru yang muncul dari rahim reformasi. Lembaga ini menjadi anggota baru dalam lembaga kekuasaan yudikatif yang sebelumnya hanya terdiri dari Mahkamah Agung dan 4 (empat) lingkup peradilan yang berada dibawahnya yaitu: lingkup peradilan umum, peradilan tata usaha negara, peradilan agama dan peradilan militer. Dasar hukum pembentukan MK dapat ditemuka dalam Pasal III aturan Peralihan yang menyebutkan bahwa “ Makamah Konstitusi dibentuk selambat-lambatnya pada 17 Agustus 2003 dan sebelum dibentuk segala

43 Markus Suryoutomo, Siti Mariyam, Akhmad Hendroyono, 2014, Parate Eksekusi atas Jaminan Fidusia (mencari model eksekusi jaminan fidusia), dalam Prosiding Konferensi Nasional Hukum Perdata "Kesiapan Hukum Perdata Indonesia menghadapi Hukum Masa Depan" (Jawa Timur: Asosiasi Pengajar Hukum Perdata) hlm. 156 
kewenanganya dilakukan oleh Mahkamah Agung". Setelah terbentuk MK diberikan 4 (empat) kewenangan dengan 1 (satu) kewajiban yang diatur dalam Pasal 24 C ayat (1) ${ }^{44}$ dan Pasal 7B UUD NRI 194545.

Putusan MK yang bersifat final dan mengikat mengakibatkan tidak ada lagi upaya hukum yang dapat dilakukan terhadap putusan tersebut selain menjalankannya. Upaya mengubahnya hanya mungkin terjadi ketika MK memutus berbeda dalam pengujian UU yang sama dengan menggunakan batu uji dan alasan permohonan yang berbeda. Sebegitu luar biasanya MK dan putusannya menyebabkan Satjipto Rahardjo mempersonifikasikannya dengan perumpaan bahwa dilidah hakim MK terdapat bara api yang fungsinya dapat memberangus kezaliman apabila digunakan dengan baik atau sebaliknya membakar hak asasi manusia apabila digunakan dengan tidak arif dan bijaksana

MK tidak hanya lembaga yang berwenang mengawal konstitusi (the guardian of constitution) tetapi MK diyakini sebagai satu-satunya lembaga peradilan yang memiliki kewenangan untuk menafsir ketentuan dalam UUD (the soul interprerter of constitution). Dalam memutus perkara pengujian UU terhadap UUD tersebut MK pada hakikinya akan menggunakan 2 model penafsiran yang umum digunakan yaitu penafsiran sesuai dengan maksud asli kehendak pembuat undang-undang dasar (the framers of constitution). Penafsiran ini dikenal dengan istilah orginalism. Atau sebaliknya MK mencoba mencari dalil didalam kebutuhan hukum masyarakat dalam menafsirakan suatu UU terhadap UUD. Penafsiran jenis ini diistilahkan dengan penafsiran non originalism.

\subsection{Jaminan Fidusia Pasca Putusan Nomor 18/PUU-XVII/2019}

Pengujian Undang-Undang Nomor 42 Tahun 1999 tentang Jaminan Fidusia ini diajukan oleh orang perorangan warga negara Indonesia sesuai dengan ketentuan Pasal 51 Undang-Undang Nomor 24 Tahun 2003 junto Undang-Undang Nomor 8 Tahun 2011 tentang Mahkamah Konstitusi. Sehingga pemohon yang bernama Aprilliani Dewi dan Suri Agung Prabowo ${ }^{46}$ memenuhi syarat legal standing dalam UU MK. Adapun Pasal yang diujikan adalah Pasal 15 ayat (2) dan ayat (3) Undang-Undang Nomor 42 Tahun 1999 tentang Jaminan Fidusia terhadap Pasal-Pasal didalam UUD NRI 1945 yang terdiri atas Pasal 1 ayat (3), Pasal 27 ayat (1), Pasal 28 D ayat (1), Pasal 28 G ayat (1) dan Pasal 28 H ayat (4) UUD NRI 1945.

Pada intinya pemohon dalam pengujian UU Fidusia ini mempersoalkan asas kepastian hukum dan legalitas kesewenangan yang dimiliki oleh penerima hak jaminan fidusia (kreditur) dalam hal terjadi cidera janji untuk melakukan eksekusi terhadap objek jaminan fidusia. Pemohon merasa norma dalam

44 Mahkamah Konstitusi berwenang mengadili pada tingkat pertama dan terakhir yang putusannya bersifat final dan mengikat (final and binding) untuk menguji undang-undang terhadap undang-undang dasar, memutus sengketa kewenangan lembaga negara yang kewenangannya diberikan oleh undang-undang dasar, memutuskan pembubaran partai politik, dan memutus perselisihan hasil pemilihan umum

45 MK wajib memberikan putusan kepada usulan DPR tatkala Presiden dan Wakil Presiden dianggap tidak lagi memenuhi syarat sebagai Presiden dan Wakil Presiden atau presiden diduga telah melakukan tindakan kejahatan dan melanggar UU.

46 Suri Agung menyampaikan dalam kasus konkret pihaknya mengalami tindakan pengambilan paksa mobil Toyota Alphard V model 2.4 A/T 2004 oleh PT Asra Sedaya Finance (PT ASF). Sebelumnya pemohon melakukan perjanjian pembiayaan multiguna atas penyediaan dana pembelian satu unit mobil mewah. Sesuai dengan perjanjian disepakati, permohon berkewajiban membayar utang senilai Rp. 222.696 .000 dengan cicilan 35 bulan terhitung 18 November 2016. Pada periode 2016-2017 kredit lancara namun setelah itu kredit macet sehingga berujung eksekusi jaminan fidusia secara paksa. Lebih lanjut baca Majalah Konstitusi Nomor 146 April 2019, (MK Press: Jakarta) hlm 30 
ketentuan tersebut hanya memberikan jaminan ham dan perlindungan kepada penerima jaminan fidusia (kreditur) semata tanpa memperhatikan secara seksama hak yang dimiliki oleh debitur yang seyogyanya juga perlu dilindungin oleh hukum dan UU. Sebab dalam kenyataannya dikarenakan konstruksi Pasal 15 ayat (2) dan ayat (3) yang mempersamakan kedudukan sertifikat jaminan fidusia dengan putusan pengadilan dengan irah-irah demi keadilan berdasarkan ketuhanan yang MahaEsa telah menimbulkan kesewenang-wenangan dan tindakan paksa yang dilakukan oleh kreditur kepada objek jaminan fidusia yang berada pada penguasaan debitur.

Padahal seharusnya menurut logika hukum yang dibangun apabila sertifikat fidusia dipersamakan dengan putusan pengadilan yang telah memperoleh kekuatan hukum tetap, maka prosedur pelaksanaan eksekusi objek fidusia seharusnya juga melalui langkah yang sama atau paling tidak serupa dengan prosedur putusan pengadilan yang berkekuatan hukum tetap (incracht van gewijde). Yaitu dengan terlebih dahulu mengajukan permohonan eksekusi kepada ketua pengadilan sebagaimana diatur dalam Pasal 196 HIR ${ }^{47}$.

Namun faktanya sebelum putusan MK ini dibacakan dan memiliki kekuatan hukum mengikat umum (erga omnes). Para kreditur seringkali mengambil secara paksa setiap objek dari jaminan fidusia yang berada dibawah penguasaan debitur tanpa adanya pernyaataan terlebih dahulu kepada pengadilan. Jika dilihat secara sepintas, mungkin maksud pembentuk UU Fidusia ini menginginkan adanya proses eksekusi jaminan fidusia yang sederhana, murah, efektid dan efesien. Sebab apabila dalam setiap eksekusi atas jaminan fidusia yang dikarenakan adanya wan prestasi dari debitur harus melalui proses mekanisme pengadilan maka kegiatan tersebut tentu akan membuat kegiatan ekonomi kreditur menjadi terhambat karena harus melalui serangkaian prosedur yang ada dipengadilan. Belum lagi dari segi pembiayaan yang kemudian harus dikeluarkan untuk mengurus administrasi. Sehingga untuk menghindari memakan waktu dan memakan biaya yang banyak tersebut maka daya eksekutorial dalam sertifikat jaminan fidusia dipersamakan dengan putusan pengadilan yang berkekuatan hukum tetap. Tidak hanya itu, adanya gap waktu dalam mengeksekusi objek jaminan fidusia dari debitur yang cidera janji akan memberi kesempatan kepada debitur untuk melakukan suatu tindakan dengan itikad tidak baik (bad faith).

Konstruksi berpikir tersebut, dapat saja dibenarkan namun disis lain, keberadaan sertifikat jaminan fidusia yang maha sakti setara dengan putusan pengadilan yang dapat dieksekusi langsung oleh pemegang atau penerima jaminan fidusia (kreditur) tentu membuka peluang untuk disalahgunakan ketika tidak ada relasi kuasa yang menyeimbangi tindakan tersebut atau ketiadaan lembaga yang dapat menilai sah atau tidak sahnya eksekusi dari objek jaminan fidusia akibat cidera janji. Sebagaimana dimaktub oleh Lord Acton "power tends to corrupts absolute power corrupts absolutely" postulat tersebut dapat diterjemahkan secara sederhana bahwa kekuasaan itu cenderung untuk disalahgunakan dan kekuasan yang besar tanpa ada pengawasan atas kekuasaan tersebut sudah barang pasti akan disalahgunakan. Adanya kekuatan yang sama pada sertifikat jaminan fidusia dengan putusan pengadilan yang berkekuatan hukum tetap membuka celah untuk disewenang-wenangkan oleh kreditur. Tindakan sewenang-wenang tersebut tentunya bukanlah tindakan yang dibolehkan dalam

47 Jika pihak yang dikalahkan tidak mau atau lalai untuk memenuhi isi keputusan itu dengan damai, maka pohak yang menang memasukan permintaan, baik dengan lisan maupun dengan surat, kepada ketua pengadilan negeri yang tersebut pada ayat pertama Pasal 195, buat menjalankan keputusan itu ketua menyuruh memanggil pihak yang dikalahkan itu serta memperingatkan supaya ia memenuhi keputusan itu di dalam tempok yang ditentukan oleh ketua, selama-lamanya delapan hari. 
hukum, bahkan dalam kaidah hukum perdata tujuan adanya hukum perdata dan hukum acara perdata salah satunya adalah untuk mencegah adanya main hakim sendiri (eigenrichting).

Ketimpangan relasi kuasa antara debitur dan kreditur atas objek jaminan fidusia inilah yang coba ditemukan titik singgungnya oleh Mahkamah Konstitusi dalam Putusannya Nomor 18/PUUXVII/2019 tersebut. Putusan ini mencoba melindungi debitur dari tindakan kreditur yang tidak baik (bad faith) vis versa putusan ini juga melindungi kreditur dari debitur yang tidak baik (bad faith).

Adanya relasi kuasa yang tidak seimbang antara kreditur dan debitur dalam jaminan fidusia sejatinya telah melanggar konsep negara hukum. Dimana didalam negara hukum salah satu cirinya menurut A.V. Dicey adalah adanya kesetaraan kedudukan (equality before the law). Indonesia adalah salah satu negara yang mendeklarasikan dirinya sebagai negara hukum secara eksplisit disebutkan dalam Pasal 1 ayat (3) UUD 1945. Sehingga hukum harus menjadi panglima dan penegak keadilan. Sejalan pula dengan ketentuan dalam Pasal 27 ayat (1) UUD NRI 1945 yang berbunyi “ segala warga negara bersamaan kedudukannya di dalam hukum dan pemerintahan dan wajib menjunjung hukum dan pemerintahan itu dengan tidak ada kecualinnya".

Jika ditelisik secara runut, argumentasi hukum yang terbentuk dalam putusan Mahkamah Konstitusi Nomor 19/PUU-XVII/2019 telah memberikan pemahaman hukum atau paradigam baru dalam mengungkap tabir pelaksanaan fidusia selama ini di Indonesia. dimana salah satu kelemahan pelaksanaan fidusia yang menciptakan relasi kuasa yang timpang bermula dari klasula baku dalam kontrak standar yang dibentuk antara kreditur (penerima fidusia) dengan debitur ( pemberi fidusia). Menurut Sutan Remy Sjahdeini, pada pemindahan hak kepemilikan atas dasar kepercayaan, hak kepemilikan secara hukum tetap ada pada pemberi fidusia. Oleh karenanya pengalihan hak milik tersebut bukan merupakan pengalihan kepemilikan secara hukum. Maka penerima fidusia (kreditur) secara hukum tidak dibenarkan melakukan perbuatan hukum apapun juga terhadap barang yang dialihkan hak kepemilikannya oleh pemberi fidusia kepada penerima fidusia. Dengan begitu penerima fidusia tidak dibolehkan menjual objek fidusia tersebut sepanjang debitur tidak telah terbukti cidera janji dan besarnya utannya yang tertunggak diakui secara sukarela oleh debitur. Sementara ketakutan penerima fidusia apabila pemberi fidusia memiliki itikad tidak baik atas barang jaminan fidusia. Maka sejatinya Pasal 36 UU No 42 Tahun 1999 sudah menjamin hak kreditur tersebut selengkapnya berbunyi "pemberi fidusia yang mengalihkan, menggadaikan atau menyewakan benda yang menjadi objek jaminan fidusia sebagaimana dimaksud dalam pasal 23 ayat (2) yang dilakukan tanpa persetujuan tertulis terlebih dahulu dari penerima fidusia, dipidana dengan pidana penjara paling lama 2(dua) tahun dan dengan paling banyak Rp.50.000.000 (lima puluh juta rupiah). Sehingga penerima fidusia tidak perlu khawatir berlebihan tatkala pemberi fidusia akan mengalihkan atau menghilangkan objek fidusia. Sehingga menurut Penulis, salah satu kelemahan dalam maraknya kasus dari perebutan objek fidusia atau pemaksaan eksekusi atas objek fidusia bisa jadi berawal dari permasalahan pengaturan kontrak standar yang tidak menjunjung kesetaraan hak antara debitur dan kreditur bukan kepada pengaturan dalam UU Fidusia an sich.

Maka Pasca Putusan Mahkamah Konstitusi Nomor 18/PUU-XVII/2019 norma hukum Pasal 15 ayat (2) dan ayat (3) mengalami perubahan yaitu menjadi konstitusional bersyarat (conditionally constitutional). Dengan begitu ketentuan tersebut akan dipandang sejalan dengan napas konstitusi apabila dimaknai sebagaimana disebutkan dalam amat putusan a quo. adapun perubahan yang terjadi dalam Pasal 5 ayat (2) dan ayat (3) tersebut dapat dilihat dalam tabel dibawah ini: 
Tabel:

Pasal 15 ayat (2) dan (3) Pasca Putusan Mahkamah Konstitusi Nomor 18/PUU-XVII/2019

\begin{tabular}{|c|c|c|}
\hline No & $\begin{array}{l}\text { Norma UU No } 42 \text { Tahun } 1999 \text { tentang } \\
\text { Jaminan Fidusia sebelum Putusan MK }\end{array}$ & $\begin{array}{l}\text { Norma UU No } 42 \text { Tahun } 1999 \text { tentang } \\
\text { Jaminan Fidusia setelah Putusan MK }\end{array}$ \\
\hline 1 & $\begin{array}{l}\text { Bunyi Pasal } 15 \text { ayat (1), (2), dan (3) } \\
\text { 1. Dalam Sertifikat Jaminan Fidusia } \\
\text { sebagaimana dimaksud dalam Pasal } 14 \\
\text { ayat (1) dicantumkan kata-kata: "DEMI } \\
\text { KEADILAN BERDASARKAN } \\
\text { KETUHANAN YANG MAHA ESA". } \\
\text { 2. Sertifikat Jaminan Fidusia sebagaimana } \\
\text { dimaksud dalam ayat (1) mempunyai } \\
\text { kekuatan eksekutorial yang sama } \\
\text { dengan putusan pengadilan yang telah } \\
\text { memperoleh kekuatan hukum tetap. } \\
\text { 3. Apabila debitor cidera janji, Penerima } \\
\text { Fidusia mempunyai hak menjual Benda } \\
\text { yang menjadi objek Jaminan Fidusia atas } \\
\text { kekuasaannya sendiri. }\end{array}$ & $\begin{array}{l}\text { sepanjang frasa "kekuatan eksekutorial" dan } \\
\text { frasa "sama dengan putusan pengadilan } \\
\text { yang berkekuatan hukum tetap" } \\
\text { bertentangan dengan Undang-Undang Dasar } \\
\text { dan tidak mempunyai kekuatan hukum } \\
\text { mengikat sepanjang dimaknai "terhadap } \\
\text { jaminan fidusia yang tidak ada kesepakatan } \\
\text { tentang cidera janji (wanprestasi) dan debitur } \\
\text { keberatan menyerahkan secara sukarela } \\
\text { objek yang menjadi jaminan fidusia, maka } \\
\text { segala mekanisme dan prosedur hukum } \\
\text { dalam pelaksanaan eksekusi sertiiikat } \\
\text { jaminan fidusia harus dilakukan dan berlaku } \\
\text { sama dengan pelaksanaan eksekusi putusan } \\
\text { pengadilan yang telah berkekuatan hukum } \\
\text { tetap. } \\
\text { Pasal15 ayat (3) sepanjang frasa "cidera janji" } \\
\text { bertentangan dengan undang-undang dasar } \\
\text { 1945 dan idak mempunyai kekuatan hukum } \\
\text { mengikat sepanjang tidak dimaknai bahwa } \\
\text { "adanya cidera janji tidak ditentukan secara } \\
\text { sepihak oleh kreditur melainkan atas dasar } \\
\text { kesepakatan kreditur dengan debitur atau } \\
\text { atas dasar upaya hukum yang menentukan } \\
\text { telah terjadi cidera janji. } \\
\text { Pasal 15 ayat (2) sepanjang frasa "kekuatan } \\
\text { eksekutorial" bertentangan dengan undang- } \\
\text { undang dasar 1945 dan tidak mempunyai } \\
\text { kekuatan hukum mengikat sepanaj tidak } \\
\text { dimaknai terhadap jaminan fidusia yang } \\
\text { tidak ada kesepakatan tentang cedera janji } \\
\text { dan debitur keberatan menyerahkan secara } \\
\text { sukarela objek yang menjadi jaminan fidusia, } \\
\text { maka segala mekanisme dan prosedur } \\
\text { hukum dalam pelaksanaan eksekusi } \\
\text { sertifikat jaminan fidusia harus dilakukan } \\
\text { dan berlaku sama dengan pelaksanaan } \\
\text { eksekusi putusan pengadilan yang telah } \\
\text { berkekuatan hukum tetap. }\end{array}$ \\
\hline
\end{tabular}

Penafsiran MK ini pada hakikatnya, memperjelas upaya perlindungan dan menemukan titik keseimbangan dalam hubungan hukum antara kreditur (penerima fidusia) dengan debitur (pemberi 
fidusia). Dengan begitu maka penerima fidusia (kreditur) kedepannya tidak dapat melakukan eksekusi atas barang fidusia secara semena-mena namun harus mematuhi ketentuan yang dipersyaratkan oleh MK dalam amar putusan nomor 19/PUU-XVII/ 2019.

\section{Kesimpulan}

Jaminan Fidusia adalah salah satu jaminan yang diatur dalam hukum jaminan yang ada dalam sistem hukum Indonesia. Sebelum berlakunya UU No 42 Tahun 1999 tentang Jaminan Fidusia. Dalam sejarah hukum fidusia di Indonesia dimulai dari adanya yurisprudensi Hoge Raad yaitu Bierbrouwerij Arret 1929. Sejak adanya arrest dari Hoogerechtshof 1932 barulah jaminan fidusia dikenal dalam sistem hukum Indonesia. Namun demi memenuhi kebutuhan hukum yang dapat lebih memacu pembangunan nasional dan untuk menjamin kepastian hukum serta memberikan perlindungan hukum bagi pihak berkepentingan barulah kemudian dibentu UU Fidusia tahun 1999.

Dalam prakteknya ternyata terdapat perbedaan dalam menafsirkan makna eksekutorial dalam sertifikat jaminan fidusia yang sering berujung dengan tidakkan main hakim sendiri (eingerichting) atau pemaksaan dalam eksekusi barang yang menjadi objek fidusia. Putusan MK Nomor 19/PUUXVII/ 2019 atas pengujian Pasal 15 ayat (2) dan ayat (3) Undang-Undang Nomor 42 Tahun 1999 tentang Jaminan Fidusia terhadap pasal-pasal dalam UUD NRI 1945 telah menyelarakan hubungan hukum yang lebih fair antara kreditur (penerima fidusia) dan debitur (pemberi fidusia). Dengan diputusnya ketentuan tersebut maka Pasal 15 ayat (2) bermakna "sepanjang frasa "kekuatan eksekutorial" dan frasa "sama dengan putusan pengadilan yang berkekuatan hukum tetap" bertentangan dengan Undang-Undang Dasar dan tidak mempunyai kekuatan hukum mengikat sepanjang dimaknai "terhadap jaminan fidusia yang tidak ada kesepakatan tentang cidera janji (wanprestasi) dan debitur keberatan menyerahkan secara sukarela objek yang menjadi jaminan fidusia, maka segala mekanisme dan prosedur hukum dalam pelaksanaan eksekusi sertiiikat jaminan fidusia harus dilakukan dan berlaku sama dengan pelaksanaan eksekusi putusan pengadilan yang telah berkekuatan hukum tetap.

Sedangkan Pasal 15 ayat (3) UU Fidusia bermakna "Pasal 15 ayat (3) sepanjang frasa "cidera janji" bertentangan dengan undang-undang dasar 1945 dan idak mempunyai kekuatan hukum mengikat sepanjang tidak dimaknai bahwa "adanya cidera janji tidak ditentukan secara sepihak oleh kreditur melainkan atas dasar kesepakatan kreditur dengan debitur atau atas dasar upaya hukum yang menentukan telah terjadi cidera janji.

Salah satu muara dari permasalahan perbedaan tafsir ini adalah adanya ketentuan dalam kontrak standar yang menciptakan ketidakseimbang hubungan hukum antara kreditur dan debitur. Sehingga hulu dari permasalahan ini adalah konflik eksekusi atas barang jaminan fidusia akibat ketentuan dalam kontrak baku yang menciptakan ketimpangan relasi kuasa debitur vis a vis kreditur.

Oleh karenanya, Otoritas Jasa Keuangan sebagai lembaga negara yang bertujuan melindungi konsumen sudah harus melakukan standardisasi atas perjanjian standar atau kontrak baku dengan membuat template perjanjian standar, isi dari perjanjian bisa beda hanya besaran bunga dan di ayatayat tertentu berbeda. Sebab apabila template sudah sama sehingga akan meminimalisir potensi penyeledupan klasul baku di dalam perjanjian standar yang menciptakan unfairness (ketidakseimbangan kedudukan para pihak). 


\section{Referensi}

Buku

Erman Rajaguguk, 1998, Transaksi Berjaminan dalam Berbagai Putusan Pengadilan di Indonesia dalam Seri Hukum Ekonomi: Hukum Jaminan Indonesia, Jakarta: ELIPS

H. Salim HS, 2012, Perkembangan Hukum Jaminan di Indonesia, Jakarta: Rajawali Press

H.U Adil, 2016, Dasar-Dasar Hukum Bisnis Edisi 2, Jakarta: Mitra Wacana Media

M. Bahsan, 2012, Hukum Jaminan dan Jaminan Kredit Perbankan Indonesia, Jakarta: Rajawali Press

Markus Suryoutomo, Siti Mariyam, Akhmad Hendroyono, 2014, Parate Eksekusi atas Jaminan Fidusia (mencari model eksekusi jaminan fidusia), dalam Prosiding Konferensi Nasional Hukum Perdata "Kesiapan Hukum Perdata Indonesia menghadapi Hukum Masa Depan" (Jawa Timur: Asosiasi Pengajar Hukum Perdata)

Munir Fuady, 2013, Hukum Jaminan Utang, Jakarta: PT Erlangga

Sobirin,2008, Kajian Hukum Terhadap Pendaftaran Jaminan Fidusia di Kantor Pendaftaran Fidusia Daerah Khusus Ibukota Jakarta, Tesis: Program Studi Magiste Kenotariatan Pasca Sarjana Universitas Diponegoro

Titik Triwulan Tutik, 2014, Hukum Perdata dalam Sistem Hukum Nasional, Jakarta: Kencana

Jurnal

Jatmiko Winarno. 2015. "Perlindungan Hukum Bagi Kreditur pada Perjanjian Jaminan Fidusia”, Jurnal Independent, Fakuktas Hukum Universitas Islam Lamongan, No. 3, Vol. 7

M Yasir. 2016. “Aspek Hukum Jaminan Fidusia”, Salam Jurnal Sosial \& Budaya Syari,i UIN syarif Hidayatullah Jakarta, Vol. 3 No. 1

Nur Hayati. 2016. “ Aspek Hukum Pendaftaran Jaminan Fidusia Berdasarkan Undang-Undang Nomor 42 Tahun 1999 tentang Jaminan Fidusia" , Jurnal Lex Jurnalica,, Vol. 13 No.2

Sugianto. 2014. "Rekontruksi Perjanjian Fidusia atas Benda Bergerak yang didaftarkan Berdasarkan Nilai Keadilan", Jurnal Pembaharua Hukum, Vol. 1 No.3

Peraturan Perundang-Undangan dan Putusan Pengadilan

Undang-Undang Dasar NRI 1945

Undang-Undang Nomor 42 Tahun 1999 tentang Jaminan Fidusia

Putusan Mahkamah Konstitusi Nomor 18/PUU-XVII/ 2019 